\title{
The Effect of Remuneration, Job Satisfaction and OCB on the Employee Performance
}

\author{
Hiqma Nur Agustiningsih", Armanu Thoyib, Djumilah H., Noermijati Noermijati
}

Faculty of Economics and Business, University Brawijaya (UB), Malang, Indonesia

\author{
Email address: \\ hiqma.niken@gmail.com (H. N. Agustiningsih) \\ ${ }^{*}$ Corresponding author
}

\section{To cite this article:}

Hiqma Nur Agustiningsih, Armanu Thoyib, Djumilah H., Noermijati Noermijati. The Effect of Remuneration, Job Satisfaction and OCB on the Employee Performance. Science Journal of Business and Management. Vol. 4, No. 6, 2016, pp. 212-222. doi: 10.11648/j.sjbm.20160406.16

Received: November 24, 2016; Accepted: December 7, 2016; Published: January 4, 2017

\begin{abstract}
This study aims to: (1) analyze the effect of remuneration, job satisfaction and Organizational Citizenship Behavior (OCB) on employee performance; (2) analyze the job satisfaction as a mediating variable of the effect remuneration on employee performance; and (3) analyze OCB role in mediating the effect of remuneration and job satisfaction on employee performance. Data was collected using saturated sampling method. The population consisted of 138 Account Representative (AR) Supervision of the work in the Tax Office in Malang area, the Regional Office of Directorate General of Taxes East Java III. Data analysis using Partial Least Squares Structural Equation Modelling (PLS-SEM) or usually called Partial Least Squares Path Modelling (PLS-PM). The results showed that the remuneration is significantly and negatively effect the performance of AR Supervision, but the satisfaction and OCB do not significantly effect the performance of AR Supervision. Furthermore, remuneration and satisfaction positively and significantly effect AR satisfaction and OCB respectively, but remuneration does not significantly effect OCB. In relation to the indirect effects, job satisfaction and OCB do not mediate the effect of remuneration on the AR Supervision performance, neither OCB mediate the effect of job satisfaction on the AR Supervision performance. The results of this study indicate that the concept of the higher the remuneration received by employees, the higher their performance will be, only occurs in normal conditions. If there are obstacles in the work implementation process, then this concept does not apply. Therefore, the Directorate General of Taxation institution must provide the solution and attention to the barriers experienced by AR Supervision in order to maximize their performance.
\end{abstract}

Keywords: Remuneration, Job Satisfaction, Organizational Citizenship Behavior, Employee Performance

\section{Introduction}

In the last two decades, Indonesia's national income tax sector increasingly important because over the years, the proportion of state revenues from the sector increases. If in 1998 the proportion of tax revenue amounted to $61.6 \%$ of the total national income, in 2004 increased to $78.3 \%$ and reached Rp. 232 trillion rupiah, comparing to tax revenue in 1994 which only amounted to 37 trillion rupiah. Even in 2015 the national tax revenue reached Rp. 1,061 trillion from Rp. 1,295 trillion target (82\%). Based on these achievements, in 2016 the target of national tax revenue set at Rp. 1.360 trillion [42].

In connection with the increasing tax revenue target, society as a whole really hope the performance of tax officials is increasing, because nearly $80 \%$ of the Indonesian budget relies on tax revenue [42]. According to Handayani, total tax revenue is highly dependent on five factors: (1) the tax system, (2) the tax regulations, (3) the tax data and information systems, (4) infrastructure and (5) human resources. Of five factors, the human resource factor, namely the tax officials becomes a very important factor in achieving the target of the tax revenue, because the state requires formidable figure tax officials that are physically and mentally strong. In addition, Luthans (2011) [35] confirms that tax officials should have the fortitude, tenacity and patience to devote his life to the nation.

Because the role of tax officials is increasingly important, their performance in their profession is very noteworthy. One of the policies pursued by the government to improve the tax officials' performance is to fix the remuneration system in order to motivate tax officials in achieving organizational 
goals [60]. As a follow up, the President has issued Presidential Regulation of the Republic of Indonesia Number 37 year 2015 about the performance benefits of employees within the Directorate General of Taxation.

Studies on the relationship between remuneration and employee performance became one of the important research in industrial-organizational psychology. Currently, the measurement of output and performance based remuneration system into the needs of public sector organizations in many countries [45]; [31]; [51]. Output and remuneration became the main characteristics of public sector reform [40]; [64]; [39]. These characteristics are intended to increase the motivation of civil servants and improve the quality of their service to the community. The characteristic diffuses into many public sectors, including the Internal Revenue Agencies [7]. Literally, the remuneration is defined as payment or remuneration stipulated by specific rules in return for a work routine [75].

According to Xiao, Henan, and Lei (2009) [74], remuneration is a form of payment or consideration given by organizations or employers with the aim to improve employee performance. Employees who receive rewards according to performance and expectations tend to perform productive and support the organization by doing positive things.

\section{Theoretical Framework and Research Hypotheses}

Dutra (2002, p.181) [14] defines remuneration as financial or non-financial received by an employee as a result of its performance. The results received are divided in the form of direct and indirect remuneration. Direct remuneration is the amount of money received by an employee for a job well done which consists of fixed and variable remuneration [10]; [14] in [30]. Indirect remuneration, on the other hand, provided by the organization for employees on the performance achieved with the aim to provide comfort and security to them, such as life insurance, health insurance, car, vacation, and other social insurance.

Utilization of the state apparatus minister (2011) [58] defines remuneration as a form of remuneration received by employees for contributions rendered to the organization. Remuneration is usually implemented to motivate employees so that they have better quality, more productive, not easily moved to other companies, establish a service-oriented behavior, and avoid corruption. Remuneration can be the form of money or salary, fixed allowances, variable allowances, incentives and other facilities. Remuneration is the total consideration received by the employees in return for the services he or she has done. In this study, the remuneration of employees of Directorate General of Taxation measured in exchange for financial and non-financial. Financial remuneration is performance benefits provided in accordance with the workload and incentives for the purpose of improving the performance of employees in realizing the tax revenues target. Meanwhile, non-financial rewards can be in the form of health insurance and/or vacation.

Furthermore, success in achieving the organization's objectives must be accompanied by the hard work of the existing human resources in the organization. Business activities can shape the development and improvement of human resources, improvement of information systems, remuneration, and other businesses. Those efforts eventually led to the efforts to improve employee performance. Davis (1996) [12] says that the performance of employees is the culmination of three elements which interrelate, namely skill, effort, and external conditions. Skills are something brought by employees to the workplace such as knowledge, intrapersonal skills, interpersonal skills, and technical skills. The skill level in this case, dealing with "what to do" employees.

Efforts are described as shown motivation of employees to accomplish the job. External conditions are the defining element of performance which support employee productivity. Furthermore, Bernardin, et al. (2001) [6] stated that the performance is a record gains resulting from a particular job function or activity in certain period. According to Bernardin, et al. (2001) [6], performance indicators are the quality, quantity, timeliness, and cost effectiveness. Meanwhile, Kiragu and Mukandala (2005) [28] explains that the employee's performance is the result of work achieved in executing tasks according to the responsibilities based on skills, experience, sincerity and punctuality.

For the measurement of employee performance, the Directorate General of Taxation adopted from Bernardin and Russel (2001) [6] and poured through letter No. S-64 / PJ.08 (2016) [33] concerning the supervision of the performance assessment taxpayers by Account Representative and Supervision and consultation devision in 2015.

In relation to remuneration influence on employee performance, Widyastuti (2010:180) [72] indicates that low compensation has an effect on employee performance. Kiragu and Mukandala (2005) [28] found that in some areas of African countries there is a close relationship between the salary and employee's performance of the bureaucracy (civil service). Research conducted by Cecilia et al (2009) [9], Schmitz (2013) [57], Effendi (2013) [15], and Kojo (2013) [29] showed that the remuneration significantly effect employee performance. Based on the above research results, the first research hypothesis is stated as follows:

Hypothesis 1: Remuneration significantly effect employee performance

Furthermore, before discussing the effect of remuneration on job satisfaction, first described the sense of job satisfaction. According to Luthans (2011) [35], job satisfaction is employee perceptions of how well a person's job in giving something that is considered important through his or her work. Meanwhile, according to Greenberg and Baron (2003:148) [21], job satisfaction is a positive or negative attitude of a person to the job. Vecchio (1995) [65] states that job satisfaction is the thinking, feelings and actions of a person's propensity for his or her attitude towards work. To measure employee satisfaction, this study refers to Luthans (2011:141-145) [35] and Robbins (2006) [54], using 
the indicator: the work itself, pay, promotion opportunities, supervision, coworkers, and work condition.

In relation to remuneration influence on job satisfaction, Luthans (2011) [35] states that employee satisfaction and dissatisfaction can affect the performance and achievement in their work. Meanwhile, Lindgren and Sanna (2008) [34], Vosloo, Fouche, and Bernard (2014) [69], and Naji (2014) [41] have consistently claimed that the remuneration effect employee satisfaction significantly. In other words, the higher the remuneration given to employees, the higher the job satisfaction of employees will be. Based on these results, the second research hypothesis is stated as follows:

Hypothesis 2: Remuneration significantly effect employee satisfaction

The Organizational Citizenship Behavior (OCB) is an individual contribution that exceeds the role demands in the workplace. OCB involves some elements of behavior, such as helping others, volunteering for extra duties, and adhere to the rules and procedures in the workplace. These behaviors describe the "value-added employee" which is a form of prosocial behavior, the positive social behavior, constructive and meaningful [2].

Other terms of OCB is an extra role behavior [4]. Organ (1997:86) [48] defines OCB as voluntary behavior, choice and individual initiatives that are not directly related to the formal reward system of the organization, but as a whole can improve the organizational effectiveness. This means that the behavior was not included in the job descriptions of employees so that if they do not carried out they would not be punished. Furthermore, Luthans (2011:149) [35] states that OCB is positively related to individual performance, group performance and organizational performance. Therefore, OCB has an essential role for the success of an organization.

Moreover, Organ (1997) [48] states that an employee who did OCB hopes to get the reward in doing his or her job. This means that financial rewards motivate someone to do OCB and is an important factor affecting satisfaction, employee performance, and organizational goals achievement. Whitecollar workers and blue collar and professional women's business in the Us who are actively do OCB get more rewards than those who do not carry out OCB [3]. Based on those results, the third research hypothesis can be stated as follows:

Hypothesis 3: Remuneration significantly effects OCB

In regard to the effect of job satisfaction on employee performance, Sudiro (2008) [59] believes that there is a significant relationship between job satisfaction and employee performance. Employees who are satisfied with what they receive in an organization would try to make the best efforts to achieve organizational goals and encourage employees to work harder and more productive. Similarly, the research results by Tissera and Fernando (2014) [62]; Vrinda and Nisha (2015) [68], and Noermijati (2015) [44] showed that job satisfaction signiificantly affects employee performance. Based on these results, the fourth research hypothesis can be stated as follows:

Hypothesis 4: Job satisfaction significantly effects employee performance
Robbins (2006) [54] found that job satisfaction is a major determinant of OCB. Employees are satisfied with their work have a greater opportunity to speak positively about the organization, help colleagues, and perform beyond the normal performance. Research by Organ and Konovsky (1989) [47], Yoon and Suh (2003) [76], Gonzales and Garazo (2006) [20], Zeinabadi (2010) [79], Rasheed, et al. (2013) [53], Zeinabadi and Salehi (2011) [80] and Salehi and Gholtash (2011) [56] found that job satisfaction significantly effects OCB. Based on those results, the fifth research hypothesis can be stated as follows:

Hypothesis 5: Job satisfaction significantly effects OCB

OCB principle involves several behavior elements which include the behavior of helping others, volunteering for extra duties, adherence to the rules and procedures in the workplace. Those positive behaviors will be able to push the work climate and conducive situation in work place where finally this working atmosphere will affect employee's performance. The better teamwork and a culture of mutual help among fellow workers, the better employee's performance will be. This positive working atmosphere leads to a comfortable working atmosphere and encourage employees to work hard and provide maximum performance for the achievement of organizational goals. Mackenzie et al. (1993) [36] found that the dimensions of OCB, such as altruism, conscience and consciousness of citizenship in accordance with the norms in Indian society had a positive impact on the individuals performance. Likewise, Vigoda and Gadot (2005) [67], Pattanaik and Biswas (2005) [49], Kim (2006) [27], Zang et al. (2011) [78], Titisari (2011) [63], Bahana (2011) [5]' and Ghalib et al. (2014) [18] stated that OCB positively and significantly effects employee performance. Based on those results, the sixth research hypothesis can be stated as follows:

Hypothesis 6: OCB significantly effects employee performance

Research by Rose and Sisira (2008) [55], Cecilia et al. (2009) [9], Schmitz (2013) [57], Effendi (2013) [15], and Kojo et al. (2013) [29] showed a significant relationship between remuneration and employee's performance. However in some cases, the high remuneration was not always affect employees performance. Studies conducted by Hussain et al. (2014) [25] on young bankers in Malaysia concluded that high remuneration did not change the intention of the bank employees to leave their job.

Previous research showed that there is a difference on the relationship between remuneration and employees performance. This shows there is a research gap between remuneration and employees performance that is interesting and important to be investigated. Referring to the above studies, this research included job satisfaction variables as a mediating variable in thee effect of remuneration on employee performance. Therefore, the seventh research hypothesis is stated as follows:

Hypothesis 7: Job satisfaction mediates the effect of remuneration on employee performance.

Research conducted by Rose and Sisira (2008) [55], Cecilia et al. (2009) [9], Schmitz (2013) [57], Effendi (2013) 
[15] and Kojo et al. (2013) [29] showed a significant relationship between remuneration and employee's performance. However, in assessing the success of the organization's performance cannot be separated from individuals behaviors. Such behaviors are positive behaviors which are performed by employees to improve the effectiveness and performance of organizations. Voluntary behavior, and individual choice and initiative do not directly relate to the reward system of the formal organizations, but in aggregate it may increase the effectiveness of organization [48]. Organ (1997) [48] further stated that an employee who did OCB hopes for rewards in doing his or her job. This means that financial rewards motivate someone to do OCB and is an important factor in affecting employees' performance. The results of the study proved that the financial rewards given to employees significantly effects their OCB [3] and [11]. Based on those results, the eighth research hypothesis is stated as follows:

Hypothesis 8: OCB mediates the effect of remuneration on employee performance.

The empirical study that examines the relationship between job satisfaction and employee performance showed a controversy since the first. Kahn (1960) [26] and Dowling (1975) [13] state that there is no relationship between job satisfaction and employee performance. In contrary, Mafini et al. (2013) [37] and Gathungu and Hannah (2013) [17] found a positive and significant correlation between job satisfaction and employee performance. This finding is consistent with research findings by Yvonne et al. (2014) [77] Choi (2015) [11], Tissera (2014) [62], Godfrey (2014) [19], and Vrinda and Nisha (2015) [68]. Furthermore, Maharani, Troena, and Noermijati (2013) [38] found that job satisfaction directly affects performance and indirectly effect it through OCB. Based on those results of the study, the ninth research hypothesis is stated as follows:

Hypothesis 9: OCB mediates the effect of job satisfaction on employee performance

\section{Research Methodology}

By its nature, this study included in the explanatory study, using a quantitative approach. Remuneration and job satisfaction data was obtained through questionnaires that use the Likert scale of five levels, from strongly agree (5) to strongly disagree (1). Furthermore, employee performance data was obtained from the Directorate General of Taxation which poured through letter No. S-64 / PJ.08 (2016) [33] relates to the performance appraisal of taxpayer supervision by Account Representative and Supervision \& Consulting division in 2015. In addition, collecting data has been done also through interviews structured and direct observation with the aim to further refine the analysis, particularly regarding Monitoring Account Representative.

The population was the whole of Account Representative Supervision, in the area of Malang Raya which is included within the Regional Office of Directorate General of Tax, East Java III, which consists of North Malang Pratama Tax Office (TO), South Malang TO, Singosari TO, Kepanjen TO, Batu TO and Madya Malang TO that consistes of 111 account Representative Supervision. Sampling method using saturated sampling which uses the entire population. The analytical tool used in this study is Partial Least Squares Structural Equation Modelling (PLS-SEM), usually called Partial Least Squares Path Modelling (PLS-PM).

\subsection{Data Analysis}

AR Monitoring Performance in Malang Regional area, Directorate General Office of Tax, Jawa Timur III is quite varie which, minimum 18 and maximum 92. The average of 44.52 with a standard deviation of 17.45 . In measuring AR Monitoring performance, the Directorate General of Taxation does not make the interval scale of the scoring result due to the characteristics of each tax office vary, such as the difference tax revenue target and the diversity of layout geografic, so that if the results of the performance appraisal was made into the intervals it would be unfair and are not comparable.

The test results of Goodness of Fit model shows that the model is fit and the whole quality indices are met. Thus the model is good and can be used to explain the phenomenon and could be used to test the hypothesis. Furthermore, the validity and reliability of test results are shown in the Table 1 . Table 1 shows, as the measuring variable, the dimension is reliable because the composite reliability coefficient and Cronbach's alpha coefficients meet the rule of thumb. All variables are also valid because Average Variances Extracted (AVE) value satisfies the rule of thumb. Therefore, all indicators are valid and reliable as the measurement of the study variables.

Table 1. Validity and reability of indicators.

\begin{tabular}{lllll}
\hline No & $\begin{array}{l}\text { Independent } \\
\text { Variable }\end{array}$ & $\begin{array}{l}\text { Composite } \\
\text { reliability }\end{array}$ & $\begin{array}{l}\text { Cronbach's } \\
\text { alpha }\end{array}$ & AVE \\
\hline 1 & Remuneration & 0.856 & 0.741 & 0.671 \\
2 & Work satisfaction & 0.826 & 0.744 & 0.447 \\
3 & OCB & 0.892 & 0.846 & 0.626 \\
Rule of thumb & $0.70 \geq$ & $0.60 \geq$ & $0.50 \geq$ \\
\hline
\end{tabular}

Table 2 shows the testing results of six direct effect hypotheses and Table 3 shows the testing results of three indirect effect hypotheses.

Table 2. Testing results of direct effect hypotheses.

\begin{tabular}{lllll}
\hline Independent Variable & Dependent Variable & Path Coefficient & p-value & Remark \\
\hline Remuneration & Employee performance & $-0.184^{*}$ & 0.022 & Accepted (negative and significant) \\
Remuneration & Work satisfaction & $0.473^{*}$ & $<0.001$ & Accepted (positive and significant) \\
Work satisfaction & Employee performance & -0.087 & 0.175 & Rejected (negative and not significant) \\
Work satisfaction & OCB & $0.703^{*}$ & $<0.001$ & Accepted (positive and significant) \\
Remuneration & OCB & 0.089 & 0.169 & Rejected (positive and not significant) \\
OCB & Employee performance & -0.077 & 0.204 & Rejected (negative and not significant) \\
\hline
\end{tabular}


Table 3. Testing results of indirect effect hypotheses.

\begin{tabular}{llllll}
\hline Mediation Variable Testing & & & & \\
Explanatory Variable & Mediation Variable & Dependent Variable & Path Coefficient & p-value & Remark \\
Remuneration & Work satisfaction & Employee performance & -0.038 & 0.401 & Rejected (negative and not significant) \\
Remuneration & OCB & Employee performance & -0.009 & 0.476 & Rejected (negative and not significant) \\
Work satisfaction & OCB & Employee performance & -0.060 & 0.363 & Rejected (negative and not significant) \\
\hline
\end{tabular}

Note: $*$ significant at $\alpha 0.05$

\subsection{Discussion}

Hypothesis 1: Remuneration significantly effects employee performance.

The results of the analysis using WarpPLS obtained path coefficients values $=-0.184$ and $p$-value $=0.022$ is significant at $\alpha=0.05$. Because $p$-value $<0.05$, then the hypothesis states that the remuneration significantly affects employee performance is accepted. Because the path coefficients are negative and significant, it can be concluded that there is a negative effect of remuneration on the employee performance. This shows that the higher remuneration value received by employees, the lower their performance will be.

This result proves that the hypothesis of remuneration effects employee performance is accepted. Based on the test of remuneration description variable for performance benefits and incentives indicators are adequate, but for health insurance and leave indicators perceived inadequate and do not meet the requirements. This shows that the remuneration indicators that consist of performance benefits, incentives, health insurance and leave effect AR Supervision performance. Based on the interviews with the Account Representative (AR) Supervision, the head of supervision, and the head office obtained information that in mid-2015 there was a reorganization in the body of the Directorate General of Taxation in accordance with the Regulation of the Minister of Finance No. 206.2 / PMK.01 (2014) [50] about Organization and Work Vertical institutions Directorate General of Taxation. As a result, tax revenues and the amount of taxpayer supervised by each AR Monitoring is reduced, the potential of the region as well as taxpayers who are supervised by AR Supervision has not been evenly distributed, whereas the tax revenue target is the same.

Uneven AR supervisory competence in analyzing and exploring the potential taxpayer also be a factor in their poor performance. In addition, there are many jobs that are AdHoc, which is not the main task of AR Supervision, as well as the performance of each AR surveillance has not been measured. This condition illustrates that there are obstacles in the work so that the AR Supervision cannot reach optimal performance. Furthermore, the decline in economic growth resulting decline in business activity taxpayers, has also an impact on the taxpayer's ability to pay. Similarly, the potential of the taxpayer becomes smaller and severely affects tax revenue target achievement by AR Supervision. The results support the research conducted by Hameed, et al. (2014) [22] who studied the effect of giving rewards to the performance of the public sector employees, the bank in Punjab, India. The results show there is a significant negative correlation between rewards and employee performance, which means that when there are additional rewards, employee performance tends to decrease. This shows that the concept of high remuneration given to employees can improve employee performance can only applies to normal conditions. When there is an obstacle in the implementation of work processes, this concept becomes invalid.

Hypothesis 2: Remuneration significantly effects employee satisfaction.

The analysis showed the path coefficient $=0.473$ and $\mathrm{p}$ value $<0.001$ was significant at $\alpha=0.05$, so the hypothesis is accepted. Because the path coefficient is positive and significant, it can be concluded that the remuneration significantly effect employee satisfaction. This shows that the remuneration received by AR Supervisions can increase their job satisfaction. Based on the results of descriptive analysis, remuneration was described quite high by the respondents, especially for performance benefits and incentives indicators. Respondents' perceptions on performance allowance indicators have the highest mean value of $3: 41$, meaning that AR Supervisions perceive that performance benefits received by them is adequate. Likewise, the incentive indicators shown a mean value of 3.20. This implies that the remuneration received by AR Supervisions can improve their job satisfaction.

These results are consistent with research findings by Lai (2011) [32] that the remuneration, either in the form of salary or other form is one of the factors that can increase employee satisfaction. This finding is also consistent with research findings by Wan (2007) [71], Lindgren and Sanna (2008) [34], Taylor (2013) [61], Vosloo, Fouche, and Bernard (2014) [69], and Naji (2014) [41] who found that the remuneration significantly effects job satisfaction. But the results of this study are not consistent with research findings by Gathungu and Hannah (2013) [17] which states that the remuneration does not significantly effect job satisfaction of the government official in Kenya; and Negwaya et al. (2014) [43] who found there is no significant effect of remuneration on employees job satisfaction in Zimbabwe; As well as Bialas et al. (2015) [8] who found that remuneration does not significantly effect employee job satisfaction of public administration in Poland.

Hypothesis 3: Remuneration significantly effects OCB.

From the analysis of the effect of remuneration on OCB obtained path coefficients value $=0.089$ and $p$-value $=0.169$ is not significant at $\alpha=0.05$, because the $p$-value $>0.05$. Therefore, the hypothesis of remuneration significantly effect on OCB is rejected. This suggests that the high-low value of the remuneration received by employees does not effect their OCB. 
The results of this study support the idea of Organ (1997) [48] who defines voluntary behavior as OCB, and states that the individual voluntary behavior does not directly or explicitly associate with the reward system and cannot increase the effective the organization functioning. This concept believes that extra person's behavior is neither relate to the presence or absence of rewards nor the size of the remuneration received by an employee. If someone does extra behavior, it is solely because of their willingness and volition, not because they hope rewards.

Hypothesis 4: Job satisfaction significantly effects employee performance.

From the analysis of the effect of job satisfaction on employee performance obtained path coefficient value $=$ 0.087 and $p$-value $=0.175$ is not significant at $\alpha=0.05$, because the $p$-value $>0.05$. Therefore, the hypothesis of job satisfaction significantly effects employee performance is rejected. This implies that the high-low job satisfaction does not effect employees performance.

Based on the distribution analysis of the respondent answers and the explanations by several head office, section head of supervision and consulting, and Account Representative, there are several factors why satisfaction does not affect the AR Supervision performance. There are many types of work performed by AR Supervisions so that they cannot focus on their main duty, which finding out the tax potential to fulfill the tax revenue target. Almost all duties in the tax office involves AR Supervision such as education and socialization, Tax gathering, reception of the annual tax payment, help desk and others.

The results of this study are consistent with the research findings by Kahn (1960) [26], Dowling (1975) [13] and Ram (2013) [52] who state that there is no relationship between job satisfaction and employee performance. But the results of this study contradict the research findings by Velnampy (2007) [66], who examined the relationship between job satisfaction and employees performance in the public sector organizations in Sri Lanka; research by Gathungu and Hannah (2013) [17] who studied at the government official in Kenya; and research by Wright et al. (2007) [73] who studied in the public service sector in the USA.

Hypothesis 5: Job satisfaction significantly effects OCB.

From the analysis of the effect of job satisfaction on $\mathrm{OCB}$ obtained path coefficients value $=0.703$ and $p$-value $<0.001$ is significant at $\alpha=0.05$. Because $p$-value $<0.05$, then the hypothesis that job satisfaction significantly effects OCB is accepted. This implies that the higher the employee satisfaction, the better the OCB will be.

Therefore, it can be explained that a satisfied employee will voluntarily work together, help each other, give advice, participate actively, provide extra service and excellence to service users, as well as use his or her time effectively. This finding supports the research carried out by Organ who states that all job satisfaction indicators such as work, co-workers, supervision, promotions, pay overall positively correlate with OCB. This study is also consistent with the research findings by Organ and Konovsky (1989) [47], Wagner et al. (2000)
[70], Yoon and Suh (2003) [76], Maharani, Troena, and Noermijati (2013) [38].

Hypothesis 6: OCB significantly effects employee performance.

From the analysis of the OCB effect on employee performance obtained path coefficient values $=-0.077$ and $p$ value $=0.204$ is not significant at $\alpha=0.05$. Because $p$-value $>$ 0.05 , then the hypothesis of OCB effect employee performance is rejected. This implies that the employees OCB does not effect employees performance.

Based on the results of interviews with the Head of the Section of Supervision and Consulting and the Head of Tax Office obtained information, that in general OCB AR Supervision is good. Not evenly potential regions and taxpayer overseen by AR Supervision accompanied by the same tax revenue target of becoming one of the low scoring performance achievement by each AR Supervision. Uneven Competence AR Supervisions in analyzing and exploring the potential taxpayer is another factor causing their poor performance. This is supported by the results of descriptive analysis where OCB are perceived by AR Supervisions in the tax office in Malang area, East Java Regional Office III. The highest average score is in the aspect of sensitivity to help friends without coercion (Altruism), especially ready to volunteer in doing something relate to the interests of the organization and to help co-workers who are having difficulties.

Cecilia et al. (2009) [9], assert that the desire of an individual to contribute cooperatively on organizational effort is something very necessary. According to Organ (1988) [46], OCB also lies in one's personal efforts in general to help other employees to accelerate the accomplishment of the task, communicate and provide direct appreciation in an effort to provide the best for organization progress.

The results of this study are not consistent with the research findings by Pattanaik and Biswas (2005) [49], Kim (2006) [27], Zang et al. (2011) [78], Titisari (2011) [63], Bahana (2011) [5], and Ghalib et al. (2014) [18] who found that OCB significantly effects employee performance.

Hypothesis 7: Job satisfaction mediates the effect of remuneration on employee performance.

Analysis results using WarpPLS and Sobel test obtained that path coefficient values of the indirect effect of remuneration on employee performance is -0.038 and $p$-value $=0.401$ is not significant at $\alpha=0.05$. Because $p$-value $>0.05$ then the hypothesis that job satisfaction mediates the effect of remuneration on the employee's performance is rejected. This shows that job satisfaction variable is not a mediating variable of the remuneration effect on employee performance.

Based on discussions and interviews with AR Supervision shows that for the job satisfaction variables, control indicators from immediate supervisor has not been able to provide enough supervision, coaching and solution as expected. Consequently, AR Supervisions perform their duties without any guidance and supervision from their immediate supervisor. For example in the process of finding out the taxpayer potential, it was found in the work condition 
indicators that the organization cannot provide a sense of security to employees, especially when there is a conflict with the taxpayer, such as when AR Supervisions are sued by the taxpayer in terms of issuing an appeal letter. Likewise for promotion indicators, AR Supervision felt that promotions lacked transparency and was not based on ability and competence of an employee. In addition, the implementation of a promotion by AR Supervision is less satisfactory due to get a diploma course adjustment had to wait a very long time with a promotion exam is not easy. As a result, the promotion process requires a very long time.

Hypothesis 8: OCB mediates the effect of remuneration on employee performance.

Analysis results using WarpPLS and Sobel test obtained path coefficient values of indirect effect -0.009 and $p$-value $=$ 0.476 is not significant at $\alpha=0.05$. Because $p$-value $>0.05$, then the hypothesis that OCB mediates the effect of remuneration on employee performance is rejected. This indicates that the OCB variable is not a mediating variable in the effect of remuneration on employee performance.

The reason given by AR Supervision is they are required to do a lot of duties at the same time, so they do not have enough time to help other AR Supervisions and cannot actively participate in the organization meetings. Therefore, the leadership of the Directorate General of Tax needs to pay more attention on the tasks and functions of AR Supervisions in order to be more focused on their main task, namely the potential exploration tax so the AR Supervisions can optimize their work in collecting tax revenue.

Hypothesis 9: OCB mediates the effect of job satisfaction on employee performance.

Results analysis using WarpPLS and Sobel test obtained path coefficient values of indirect effect -0.060 and $p$-value $=$ 0,363 is not significant at $\alpha=0.05$. Because $p$-value $>0.05$, then the hypothesis that the OCB mediates the effect of job satisfaction on employee performance is rejected. This shows that the variable of OCB is not a mediating variable in the effect of job satisfaction on employee performance.

Based on the interviews with AR Supervision found that duties and functions of AR Supervisions who often do a lot of ad hoc work is one of the reasons they cannot optimize in helping other AR Supervisions. This means that the AR Supervisions are less satisfied with their work conditions. Based on the theory of justice (equity theory), a person will feel satisfied or dissatisfied are dependent on justice in a situation, especially in work situations. Input is a valuable factor for employees who are considered to support work such as education, experience, skills, the number of tasks and equipment or equipment used to perform work [1].

The result is something that is considered valuable by an employee obtained from his or her job as a wage or salary, symbol, status, awards and the opportunity to succeed or selfactualization. According to this theory, every employee will compare the results of other people's input ratio. When a comparison was considered fair, the employee will be satisfied. If the comparison is not balanced but profitable may lead to satisfaction or dissatisfaction. If the comparison is not balanced then there will be dissatisfaction. This is in accordance with the test weight of factors that job satisfaction variable is determined more by the working condition indicators. The results of this study are not consistent with the research findings by Maharani et al. (2013) [38] who found that the OCB mediates the effect of job satisfaction on the employees' performance at Mandiri Syariah Bank in Malang, East Java.

\section{Conclusions and Recommendations}

Remuneration is an important factor that motivates $A R$ Supervision to perform better and do positive things for the organization. Furthermore, employee satisfaction can stimulate a person to behave pro-socially such as positive social behavior, constructive and meaningful help. Thus, in order to improve employee performance to note some important variables that contribute to the achievement of optimal performance that remuneration, job satisfaction and OCB of AR Supervision.

In detail, the results of this study can be concluded that the remuneration has a significantly and negatively effect on AR Supervision performance. This indicates that the higher the value of the remuneration received by AR Supervision, the lower their performance will be. The negative effect occurs because there are some obstacles in the implementation process of AR Supervision tasks, such as not optimal of data accessibility and availability to support the AR Supervision main tasks in exploring tax potential. Another obstacle is the reorganization of the Directorate General of Tax body in mid-2015 that adapts the Minister of Finance regulation No. 206.2/PMK.01 (2014) [50] regarding organization and working system of Vertical Institutions Directorate General of Taxation, which resulted in changes in the target and the number of Tax Payer supervised by each AR Supervision. As a result, the number of taxpayers and the realization of revenue received by AR supervision also declined. Uneven potential regions and taxpayers supervised by AR Supervision, similar amount tax revenue target, a lot of work that is Ad-Hoc and excludes from AR Supervision primary tasks, and not measurability of the performance of each AR Supervision, be other inhibiting factors that also need attention from the Directorate General of Taxation.

Furthermore, the fair, equitable and proportionate remuneration will encourage the increase of employee satisfaction. To maintain job satisfaction in the future, AR Supervisions hope that remuneration in the form of performance benefits in a fair manner and proportionally based on the workload and the individual performance achievement. Also, there is clarity on the provision of incentives mainly basic incentives, the amount and time of incentive. Besides the organization provides proper health and life insurance, as well as the harmonization of rules on maternity leave according to the employees needs must be considered.

Some job satisfaction indicators such as job promotion, assignment and workload, and lack of supervision or direction of the immediate supervisor needs attention from 
the leadership of the Directorate General of Taxation. Promotion system in the DGT is still not entirely based on the performance of AR Supervision. Power and education are still dominant factors. Research findings show that some AR Supervision with ordinary abilities, especially in exploring the taxpayer potential but are promoted to a higher position. Finally, the presence of diverse job done by AR Supervision render them unable to focus on their main job, which is exploring the tax and taxpayer potential to meet the tax revenue target.

A high job satisfaction on the work condition and colleagues were able to increase the AR Supervision OCB. An increase in AR Supervision job satisfaction due to the working conditions in the form of good relationship, familiar among fellow employees, and comfortable office condition makes them more motivated in improving their OCB, get better way to perform their duties and tasks in accordance responsibilities in order to increase their social awareness such as helping other AR supervisions, and avoiding harmful behaviors that can endanger the organization.

The remuneration received by AR Supervisions does not encourage their OCB behaviors. It is caused by a variety of tasks that excludes from their main duties, so they cannot help other AR Supervisions optimally. In addition, remuneration is disproportionate among employees, which may lead to jealousy so they become less concerned to other employees. For example, there is reluctance in providing voluntary assistance in the tasks, including reluctant to give opinion on the problems experienced by colleagues.

Not optimal role of employers in providing supervision, coaching and solutions as expected, and yet optimal back-up or security to the AR Supervision in the work implementation process, especially when there is a conflict with the taxpayer, the implementation of the promotion is less satisfactory, and the barriers in the work implementation process that trigger the AR Supervisions dissatisfaction towards their work lead to job satisfaction and OCB variables were not capable to act as mediator in the effect of remuneration on employee performance.

This study has limitations as this only used cross section data obtained from a specific time. In addition, this study is limited to the AR Supervision in Malang area that has not been able to explain comprehensively from the scope of the entire AR Supervision in other areas. Therefore, it gives an opportunity to the next researchers in considering broader research area of the tax offices, so the research findings can be widely generalized.

\section{References}

[1] Adams, John S. 1963. Toward an Understanding of inequity. Journal of Abnormal and, Social Psychology, 67 (5), p. 422436.

[2] Aldag, R., dan Reschke, W. 1997. Employee Value Added: Measuring Discretionary Effort and Its Value to The Organization. Center for Organization Effectiveness. Inc. 608/833-3332, p. $1-8$.
[3] Allen, T. D. 2006. Rewarding good citizens: The relationship between citizenship behavior, gender, and organizational rewards. Journal of Applied Social Psychology, 36, p. 120-143.

[4] Alotaibi, Adam G. 2001. Antecedent of Organizational Citizenship Behavior: A Studi Public of Public Personnel in Kuwait, Public Personnel Management, September, vol. 30 no. 3, p. 363-376, ABI/Inform Research.

[5] Bahana, La Ode Adam. 2011. Peran Motivasi Spiritual Agamis Terhadap Organizational Citizenship Behavior (OCB) dan Kinerja Dosen (Studi Pada Dosen Universitas Haluoleo Kendari Sulawesi Tenggara), Disertasi. Program Doktor Ilmu Manajemen, Universitas Brawijaya.

[6] Bernardin, H. John dan Russel J. E. A. 2001. Human Resources Management, Second edition, McGraw-Hill Inc, Singapore.

[7] Bertelli, A. M. 2006. Motivation crowding and the federal civil servant: Evidence from the US Internal Revenue Service. International Public Management Journal, 9, p. 3-23.

[8] Bialas, Sylvia., Joanna L, and jaroslaw W. 2015. The Relation between Remuneration and Job Satisfaction: A case study of Public Administration employees in Pomerania Region in Polland. Social and Labour Relations, p. 123-133.

[9] Cecilia Bernsten., Karolina Andersson., Yves Gariepy., Steven Simoens. 2009. A comparative analysis of remuneration models for pharmaceutical professional services. Science Direct. Elsevier Ireland Ltd. All rights reserved.

[10] Chiavenato, I. 2000. Sumberdaya Manusia. Sao Paulo: Atlas.

[11] Choi, W. Seok, Jun Seok Heo, and Lee-Jeong Kim. 2015. A Study on the Impact of Material, Social, Symbolic Reward on OCB: Moderate Effect of the Rank, Journal of Economics, Business and Management, Vol. 3, No. 3, March, p. 377-382.

[12] Davis, Keith. 1996. Human Resource and Personnel Management. $4 \mathrm{Ed}$, International Edition, Singapore: $\mathrm{Mc}$ Graw Hill Book Co.

[13] Dowling, W. F. 1975. Conversation with George C. Homans, Organizational Dynamics, Autumn, pp. 34-54.

[14] Dutra, J. S. 2002. Gestao de pessoas (People Management). Sao Paulo: Atlas.

[15] Effendi, Ardinal. 2013. Pengaruh Remunerasi dan Motivasi berprestasi terhadap Anggota POLRI di Direktorat Reserse Kriminal Khusus Polda Riau. Tesis. Universitas Terbuka.

[16] Fart J. L., Zhong C. B., and Organ, D. W. 2004. Organizational Citizenship Behavior in The people's Republic of China Organization Science, 15: p. 241-253.

[17] Gathungu, James. and Hannah, W. Wachira. 2013. Job Satisfaction Factors that Influence the Performance of Secondary SchoolPrincipals in their Administrative Functions in Mombasa District, Kenya, International Journal of Education and Research, Vol. 1 No. 2 February, p. 1-15.

[18] Ghalib, S. Bambang Swasto, Suharyono., Djamhur Hamid. 2014. The Effects of Leadership Style to the Employees' Performance of "Bank Kalsel" through Communication Satisfaction Mediation Variable, Organizational Commitment, and Organizational Citizenship Behavior (OCB). European Journal of Business and Management www.iiste.org, Vol.6, No.13, p. 163-170. 
[19] Godfrey, Segawa. 2014. Factors Influencing Employee Job Satisfaction and its impact on Employee Performance: A Case of Unilever Kenya, A Research Project Submitted to Chandaria School of Business in Partial Fulfillment of the Requirement for the Degree of Masters in Business Administration (MBA), United States International University, Spring.

[20] Gonzales, Jose Varela dan Garazo, Teresa Garcia. 2006. Structural relationship between organizational service orientation, contact employee job satisfaction and citizenship behavior, International Journal of Service Industry Management, Vol. 17 No. 1, p. 23-50.

[21] Greenberg, J., \& Baron, R. A. 2003. Behavior in organizations: Understanding and managing the human side of work (5th Ed), Upper Saddle River, NJ: Prentice Hall.

[22] Hameed. A, M. Ramzan, Hafiz M. Kashif Zubair, Ghazanfar Ali, M. Arslan. 2014. Impact of Compensation on Employee Performance (Empirical Evidence from Banking Sector of Pakistan). International Journal of Business and Social Science. Vol. 5 No.2; February, p. 302-309.

[23] Handayani, Ririn Dengan Pajak Kita Wujudkan Kemandirian Bangsa: Hubungan Tax Ratio dengan Kemandirian Bangsa. Direktorat Jenderal Pajak Departemen Keuangan RI.

[24] Hillman, Arye L 2004. Corruption and Public finance: an IMF perspective. European Journal of Political Economy, Vol. 20 pp. 1067-1077.

[25] Hussain, I. A. N. Yunus, N. A. Ishak, N. Daud. 2014. Does Remuneration Influence the Intention to Leave?: A Preliminary Study among Young Bankers in Malaysia, Procedia -Social and Behavioral Sciences, 130, p. 186-192, Elsevier Ltd.

[26] Kahn, R. L., 1960. Productivity and Job Satisfaction. Personnel Psychology, Autumn, pp. 275-287.

[27] Kim, Sangmook. 2006. Public Service Motivation and Organizational Citizenship Behavior in Korea, International Journal of Manpower, Vol. 27, No. 8, p. 722-740.

[28] Kiragu, K and Mukandala, R. 2005. Politics and Tactics in Public Sector Reforms: The Dynamics of Public Service Pay in Africa. Dar es Salaam University Press.

[29] Kojo, Alex Osei., Emmanuel, Yeboah Assiamah and Kwame, Asamoah. 2013. Enhancing Public Sector Productivity in Ghana: A Qualitative Study, Journal of Public Administration and Governance, ISSN 2161-7104, Vol. 3, No. 3.

[30] Krauter, Elizabeth and Almir Ferreira de Sousa D. S.2008. Executive Remuneration and Corporate Performance. http://www.progep.org.br/MelhoresEmpresas/InfoDocs/KRA UTER\%20E 2008 EXECUTIVE\%20REMUNERATION\%2 OAND\%20CORPORATE\%20PERFORMANCE. pdf, diakses pada tanggal 14 Mei 2015.

[31] Lah, T. J., \& Perry, J. L. 2008. The diffusion of the Civil Service Reform Act of 1978 in OECD countries: A tale of two paths to reform. Review of Public Personnel Administration, September, 28, p. 282-299.

[32] Lai., Hsin Hsi. 2011. The influence of compensation system design on employee satisfaction. African Journal of Business Management Vol.5 (26), pp. 10718-10723, 28 October, 2011 Available online at $h t t p: / / w w w . a c a d e m i c j o u r n a l s . o r g / A J B M$.

[33] Letter No. S-64/PJ.08/2016 Concerning the supervision of the performance assessment taxpayers by Account Representative and Supervision and consultation devision in 2015.

[34] Lindgren, Linda and Sanna Paulsson. 2008. An Explanatory Study of Swedish employees in The Financial sector regarding leadership style, Remuneration and elements towards Job Satisfaction. Inu. diva-portal. org. Januari.

[35] Luthans, Fred. 2011. Organizational Behavior, An EvidenceBased Approach, Twelfth Edition, Mc. Graw Hill.

[36] MacKenzie, S. B., Podsakoff, P. M and Fetter R. 1993. The impact of Organizational Citizenship Behavior on Evolution of Salesperson Performance, Journal of Marketing, Vol. 57, p. 70-78.

[37] Mafini, Chengedzai., David R. I. Pooe. 2013. The relationship between employee satisfaction and organisational performance: Evidence from a South African government department. Journal of Industrial Psychology, Vol. 39, No. 1, p. $453-462$.

[38] Maharani, V., Troena, E. A., \& Noermijati. 2013. Organizational Citizenship Behavior Role in mediating the Effect of Transformational Leadership, Job Satisfaction on Employee Performance: Studies in PT Bank Syariah Mandiri Malang East java. International Journal of Business and Management, 8 (17), p. 1-12.

[39] Mascarenhas, R. C. 1993. Building an enterprise culture in the public sector: Reform of the public sector in Australia, Britain, and New Zealand. Public Administration Review, 53, p. 319328 .

[40] McNulty, T., \& Ferlie, E. 2004. Process Transformation: Limitations to radical organizational change within public service organizations. Organization Studies, 25, p. 1389-1412.

[41] Naji, Abdel H. 2014. Components of Remuneration and Employee Satisfaction: The Impact of Effort Rewards and career Advancement. International Journal of Arts \& Sciences, 07 (02), p. 425-436.

[42] Nasution, Darman. 2005. Dengan Pajak Kita Wujudkan Kemandirian Bangsa. Cetakan I. Direktorat Jenderal Pajak Departemen Keuangan RI.

[43] Negwaya, Edward., Tendai Chazuza, Nyasha $M$ and Anastancia M. 2014. Investigation of Staff Perceptions Regarding the Impact ofRemuneration Equity on Job Satisfaction in a Zimbabwean Local Authority: The case of Chaminuka R. D. C. International Review of Management and Business Research. March 2014. Vol. 3 Issue.1, p. 150-161.

[44] Noermijati, D. Primasari. 2015. The Effect of Job stress and Job motivation on employees' performance through job satisfaction (A study at PT. Jasa marga (Persero) Tbk. Surabaya-Gempol branch). Journal of Economics, Business, and Accountancy Ventura. Vol. 18, No. 1, August-November, p. 231-240.

[45] OECD. 2003. Performance related pay of government employees: assessing reforms across OECD Member Countries. Paris: OECD Public Governance and Territorial Development Directorate, Public Management Committee.

[46] Organ, D. W. 1988. Organizational Citizenship Behavior: The Good Soldier Syndrome. Lexington, MA: Lexington Books.

[47] Organ, D. W., and Konovsky, M. 1989. Cognitive versus Affective Determinants of Organizational Citizenship Behavior. Journal of Applied Psychology, 74, p. 157-164. 
[48] Organ, D. W. 1997. Organizational Citizenship Behavior: It's Construct Clean-Up Time. Human Performance, vol.10 no. 2. p. 85-97.

[49] Pattanaik, S and Biswas, S. 2005. The Mediating Role of Organizational Citizenship Behavior Between Organizational Identification and Its Consequences, Paper.

[50] Minister of Finance No.206.2/PMK01/2014 about Organization and Work Vertical institutions Directorate General of Taxation.

[51] Perry, J. L., Engbers, T. A., \& Jun, S. Y. 2009. Back to the future? Performance-related pay, empirical research, and the perils of persistence. Public Administration Review, 69, p. 39 51.

[52] Ram, Padmakumar. 2013. Relationship between Job Satisfaction and Job Performance in the Public Sector-A Case Study from India, International Journal of Academic Research in Economics and Management Sciences, March 2013, Vol. 2, No. 2 ISSN: 2226-3624.

[53] Rasheed, Anwar. Khawaja Jehanzeb, dan Mazen F. Rasheed. 2013. An Investigation of the Antecedents of Organizational Citizenship Behaviour: Case of Saudi Arabia, International Journal of Psychological Studies; Vol. 5, No. 1, p. 128-138.

[54] Robbins, Stephen P. 2006. Organizational Behavior, PrenticeHall International, Inc.

[55] Rose, Anne Devlin and Sisira Sarma. 2008. Do physician remuneration schemes matter? The caseof Canadian family physicians. Journal of Health Economics 27, 1168-1181.

[56] Salehi, M., \& Gholtash. A. 2011. The Relationship between Job Satisfaction, Job burnout \& Organizational Commitment with the OCB among members of faculty in the Islamic Azad University-first district branches, in order to provide the appripriate model. Prestige Journal of Management and Research, 15. p. 306-310.

[57] Schmitz, Hendrik. 2013. Practice budgets and the patient mix of physicians - The effect of aremuneration system reform on health care utilisation. Journal of Health Economics. 32, p. $1240-1249$.

[58] State Apparatus Minister. 2011. Remuneration or renumeration. http://remunerasi-pns-tnipolri.blogspot.co.id/2011/10/remunerasi-atau-renumerasi.html.

[59] Sudiro, Achmad. 2008. Pengaruh Timbal Balik Antara Kepuasan Kerja dengan Kepuasan Keluarga dan Komitmen Kerja serta Dampaknya terhadap Prestasi Kerja dan Karier Dosen, Jurnal Manajemen dan Kewirausahaan, Vol. 10 No. 1, hal. 38-49, Universitas Kristen Petra Surabaya.

[60] Susiwijono. 2015. Besaran Remunerasi pegawai pajak akan sesuai capaian penerimaan.

http://www.beritasatu.com/ekonomi/250946-kemkeu-besaranremunerasi-pegawai-pajak-akan-sesuai-capaianpenerimaan.html.

[61] Taylor, Jeannette. 2013. Remuneration Policy in the Australian Public Service: Fairness and Trust, Australian Political Studies Association Annual Conference, Murdoch University, Perth, 30 September - 2 October 2013.

[62] Tissera P M N P dan Fernando L. S. 2014. Impact of Job Dissatisfaction on Performance of the GramaNiladhari officers in Kalutara Divisional Secretariat in Srilanka. 11th International Conference on Business Management, p. 234252.

[63] Titisari, Purnamie. 2011. Organizational Citizenship behavior (OCB): Variabel Anteseden dan Pengaruhnya Terhadap Kinerja Pegawai Pada Kantor Pelayanan Perbendaharaan Negara Kantor Wilayah Jawa Timur. Disertasi. Universitas Brawijaya Malang.

[64] Varone, F., \& Giauque, D. 2001. Policy management and performance related pay: Comparative analysis of service contracts in Switzerland. International Review of Administrative Sciences, 67, p.543-565.

[65] Vecchio, R. P. 1995. It's not easy being green: jealousy and envy in the workplace. G. R. Ferris (Ed.), Research inpersonnel and human resources management, vol. 13 (pp. 201-244). Greenwich, CT: JAI Press.

[66] Velnampy, T. 2007. Job Attitude and Employees Performance of Public Sector Organizations in Jaffna District, Sri Lanka. GITAM Journal of Management 01/2007; 6 (2), p. 1-11.

[67] Vigoda and Gadot, E. 2005. "Leadership, Style, Organizational Politics and Employees' Performance, An Empirical Examination of Two Competing Models,'. Personnel Review. Vol. 36, No. 55, p. 661-683.

[68] Vrinda, N N, dan Nisha A. Jacob. 2015. The Impact of Job Satisfaction on Job performance. International Journal in Commerce, IT \& Social Sciences. Vol.2 Issue-2, February, p. 27-37.

[69] Vosloo, Wilmie., Fouche, Jaco., and Barnard, Jaco. 2014. The Relationship Between Financial Efficacy, Satisfaction With Remuneration And Personal Financial Well-Being. International Business \& Economics Research Journal, November/December Volume 13, Number 6, p. 1455-1470.

[70] Wagner, Sharon L. And Rush, Michael C. 2000. Altruistic Organizational Citizenship Behavior: Context, Disposition and Age, The Journal of Social Psychology, Vol. 140. p. 379391.

[71] Wan, Hooi lai. 2007. Remuneration Practices in the Chemical Industry in Malaysia: The Impact on Employee Satisfaction. Research note. Compensation and Benefit Review. July/August. Sage Publications.

[72] Widyastuti, Y. 2010. Pengaruh Persepsi Remunerasi pegawai, Motivasi Kerja dan Disiplin Kerja terhadap Kinerja Pegawai di Kantor Pelayanan Perbendaharaan Negara (KPPN) Percontohan Serang Provinsi Banten. Jurnal Administrasi Publik. Volume 1, No. 2, p. 179-195.

[73] Wright, T. A., R. Cropanzano and D. G. Bonett, 2007. The moderating role of employee positive well being on the relation between job satisfaction and job performance. Journal of Occupational Health Psychology, 12(2): p. 93-104.

[74] Xiao, Qian. Henan Qi, Lei Xiao. 2009. Total Reward Strategy: A Human Resources Management Strategy Going with the Trend of the Times. International Journal of Business Management. Vo. 4 No. 11.

[75] Ying Li-Jin and Jun We Ya. 2010. "The Remuneration of Management Studies Based on Marginal Utility Theory". Advance Management Science (ICAMS), 9-11 July 2010. p. 587-590. 
[76] Yoon, Mahn Hee and Suh, Jaebom. 2003. Organizational Citizenship Behaviour and Service Quality as External Effectiveness of Contact Employees. Journal of Academy of Marketing Science, vol 11, no. 4, p. 121-132.

[77] Yvonne, Wong, R. Husna Abdull Rahman and Choi, Sang Long. 2014. Employee Job Satisfaction and Job Performance: A Case Study in a Franchised Retail-Chain Organization. Journal of Applied Sciences, Engineering and Technology 8 (17), p. 1875-1883.

[78] Zang, Kai, Changquan Jiao, David A. Richards. 2011. Leadership and Organizational Citizenship Behavior: OCB-
Spesific Meanings as Mediators, Journal of Business \& Psychology, March, Volume 26, Isssue 1, p. 11-25.

[79] Zeinabadi, H., 2010. Job satisfaction and Organizational commitment as Antecedents of Organizational Citizenship Behavior (OCB) of Teachers. Science direct Procedia Social and Behavioral Sciences, 5, p. 998-1003.

[80] Zeinabadi, H., \& Salehi, K. 2011. Role of Procedural Justice, Trust, Job Satisfaction, and Organizational Commitment in OCB of Teachers: Proposing \& modified Social Exchange Model. Procedia-Social and Behavioral Sciences, 29, p. $1472-$ 1481 . 